\title{
Diel horizontal migration of the Hawaiian mesopelagic boundary community observed acoustically
}

\author{
Kelly J. Benoit-Bird ${ }^{1, *}$, Whitlow W. L. Au ${ }^{1}$, Russell E. Brainard ${ }^{2}$, Marc O. Lammers ${ }^{1}$ \\ ${ }^{1}$ Hawaii Institute of Marine Biology and Department of Zoology, University of Hawaii, PO Box 1106, Kailua, Hawaii 96734, USA \\ ${ }^{2}$ Southwest Fisheries Science Center, National Marine Fisheries Service, Honolulu Laboratory, 2570 Dole Street, Honolulu, \\ Hawaii 96822, USA
}

\begin{abstract}
The mesopelagic boundary community off the leeward coasts of 2 Hawaiian Islands, Oahu and Hawaii, was investigated with an echosounder modified to read directly into a laptop computer. Acoustic sampling was conducted over a total distance of $12.6 \mathrm{~km}$ off the Waianae coast of Oahu and $46.3 \mathrm{~km}$ off the Kona coast of Hawaii. The density of organisms was determined using echo energy integration, and relative abundance was determined in a way analogous to catch-per-uniteffort. The vertical range of mesopelagic organisms expanded as the mesopelagic layer rose and then compressed as it descended. The vertical range of the layer off the Kona coast was larger than that off the Waianae coast, possibly because of the greater bottom depth off Kona. Near midnight, the boundary community $3 \mathrm{~km}$ from the shoreline was split into 2 distinct layers, one beginning approximately $25 \mathrm{~m}$ from the surface and one beginning approximately $90 \mathrm{~m}$ from the surface. The density and the relative abundance of mesopelagic organisms were consistently higher off the Waianae coast than the Kona coast. However, the density of organisms observed in both locations was high, reaching a maximum of 1800 organisms $\mathrm{m}^{-3}$ off Waianae and 700 organisms $\mathrm{m}^{-3}$ off Kona. The maximum relative abundance off Waianae neared $100 \%$, while off Kona it never exceeded $70 \%$. In both locations, organisms were found within $1 \mathrm{~km}$ of shore, in waters much shallower than their assumed daytime habitat. The temporal patterns of relative abundance and density of organisms in waters closest to the shores of each island resembled a bell curve, with a peak in relative abundance and density around midnight. In waters further from shore, the temporal patterns in relative abundance and density had a bimodal distribution, with peaks around both 21:00 and 03:00 $\mathrm{h}$. These patterns in relative abundance and density are significantly affected by the distance of the sampling location from the shoreline, but not by the depth of the sampling site. The data suggest that the organisms of the mesopelagic boundary community undergo a diel horizontal migration that is reciprocal, $1.8 \mathrm{~km}$ in $2 \mathrm{~h}$ toward shore and then the same distance in approximately the same amount of time away from shore, in addition to their well-established vertical migration. The temporal patterns of the horizontal component of the migration are predictable and are conserved between days, phases of the moon, seasons, and islands.
\end{abstract}

KEY WORDS: Mesopelagic boundary community $\cdot$ Diel horizontal migration $\cdot$ Diel vertical migration · Acoustic sampling $\cdot$ Hawaiian Islands

\section{INTRODUCTION}

The mesopelagic boundary community in the Hawaiian Islands was first described by Reid et al.

*E-mail: benoit@hawaii.edu
(1991) as a distinct resident community of micronekton distributed along a narrow band where the upper slopes of the islands meet the oceanic mesopelagic environment. This community, comprised of various species of fishes, shrimps, and squids, some of which undergo diel vertical migrations, has a composition unique to the boundary region (Reid et al. 1991). 
Many hypotheses have been advanced to explain why communities around islands and seamounts are so different from surrounding oceanic communities. Habitat complexity, which is greater on the slopes of islands and seamounts than the surrounding flat sediment, has long been hypothesized to have an effect on primary production (Hunter \& Price 1992). More direct inputs from the island's slope through benthic communities or from land-based inputs have also been hypothesized to affect primary production (Rogers 1994). Oceanographers have suggested that the complex effects that islands and seamounts have on ocean circulation can affect production and recruitment (Rogers 1994) and that the upwelling caused by the islands increases productivity (Kennett 1982). All these ideas suggest that there is an increase in primary production surrounding the Hawaiian Islands (Karl et al. 1998, Hassett \& Boehlert 1999). The suggestion that there is an increased density of consumers of primary production around islands and seamounts, however, has not been thoroughly tested (Rogers 1994).

Gut-content analyses of tuna (He et al. 1997), billfish (Skillman 1998), bottomfish (Haight et al. 1993), and spinner dolphins (Norris et al. 1994) in Hawaii have established that much of their prey is taken from the mesopelagic boundary community. The mesopelagic boundary community is an important component of the coastal ecosystem in Hawaii, and probably of other Pacific islands and seamounts. Rogers (1994) noted that the biomass of available forage is a key factor in controlling the abundance and distribution of tropical tunas because tunas have high energy demands and live in a food-poor environment. He also noted that estimation of the density, abundance, and distribution of this forage had not been possible with the techniques used to date.

Despite the importance of the mesopelagic boundary community to pelagic and benthic predators around the Hawaiian and Pacific islands, this layer has not been well studied. Our knowledge of the species composition, distribution, and movements of the pelagic fauna of the boundary region is minimal (Reid et al. 1991). Only one study has concentrated on this important zone (Reid 1994) while two others have looked at it incidentally (Struhsaker 1973, Amesbury 1975). All these studies used trawling as their primary method of study. While these studies have been very valuable in identifying species and obtaining some general information about the spatial structure of this boundary community of micronekton, trawling techniques have severe disadvantages. Trawling studies are relatively localized (Reid's work consisted of 3 stations around the island of Oahu and another 11 stations around the islands of Molokai, Lanai and Maui). Trawls large enough to capture micronekton must be launched from a large and expensive ship and are usually undertaken in relatively deep water due to the risk of encountering the ocean floor. Trawls cannot track the horizontal movements of organisms effectively. Most importantly, there is an inherent bias associated with 'net avoidance' (see, for example, Holliday \& Pieper 1995, Medwin \& Clay 1998). In one study combining trawl sampling with acoustic methods, acoustic sampling estimates of biomass were 7 times greater than trawl estimates (Koslow et al. 1997). Sampling with nets yields a highly biased assessment of overall biomass of marine pelagic communities (Kenchington 1989). The natural heterogeneity, both in space and time, of the distribution of a pelagic community also introduces errors into estimates of density derived from sampling with nets. The combined errors make it impossible for trawling studies to address the heterogeneous distribution of overall community abundance and density as well as its movement (Koslow et al. 1997). Trawling studies are the best way to address questions related to species composition; however, other techniques are required to address questions of spatial and temporal patterns of the community. Because of problems with net avoidance and bottom collisions associated with trawling, Reid et al. (1991, p 436) suggested that '(f)uture sampling of this community will have to be adapted to the unique logistic requirements of the boundary zone'.

It has been difficult, until now, to effectively assess the fine-scale movements of highly mobile prey, such as organisms in the mesopelagic boundary community. A description of prey movement is crucial to understanding the dynamics of a predator population (Haury et al. 1978). Diel vertical migrations of mesopelagic organisms are well documented (Roe 1974). It is hypothesized that organisms within the community migrate vertically to find food and avoid predators (Enright 1977). Nocturnal horizontal migration of both plankton and consumers into shallow waters is common in lake systems (DeMeester et al. 1993, Comeau \& Boisclair 1998, White 1998). It is hypothesized that these horizontal migrations, like the vertical migrations that they often accompany, help organisms find food and avoid predators (White 1998). Diel horizontal migrations have also been observed in marine copepods (Suh \& Yu 1996 ) and mysid shrimps (Suh et al. 1995) in Korean waters, and in marine amphipods in waters off Europe (Lindstrom 1991) and in mysid shrimps off South Africa (Webb \& Wooldridge 1990). Mesopelagic organisms such as the shrimp Sergia lucens (Omori \& Ohta 1981) and the squid Watasenia scintillans (Sasaki 1914) exhibit diel shoreward horizontal migrations in Japanese waters. In fact, the horizontal migration of $W$. scintillans is so predictable that a commercial fishery is based on its landward migra- 
tion. (The horizontal migration of Sergia lucens was discovered and has been studied using a complement of non-traditional techniques including sonar and video sampling [Omori \& Ohta 1981].)

The primary goals of this study were to: (1) develop an acoustic sampling technique to address questions of spatial heterogeneity of the community as a whole (community scale patchiness) and deal with shallow depths; (2) assess the relative abundance and density of the community; (3) assess the nighttime horizontal and vertical spatial distribution of the density and relative abundance of mesopelagic organisms, both along and across the slope of the Hawaiian Islands; (4) assess temporal patterns in relative abundance and density; (5) assess how oceanographic parameters are related to these patterns.

\section{METHODS}

Waianae. The Waianae coast of Oahu, Hawaii, was acoustically sampled using a $10 \mathrm{~m}$ vessel traveling at $2.6 \mathrm{~m} \mathrm{~s}^{-1}$ (5 knots) over the bottom. Circular transects $100 \mathrm{~m}$ in diameter were surveyed for $1 \mathrm{~h}$, at $3 \mathrm{~h}$ intervals, starting $1 \mathrm{~h}$ before dusk (18:00 h) and ending $1 \mathrm{~h}$ after dawn (06:00 h) on July 5 to 30 1999. On average, 12 sites could be sampled each hour. Sampling was conducted primarily during dark periods because the mesopelagic boundary community has a well-documented diel vertical migration and would be too deep (400 to $1200 \mathrm{~m}$ ) to be detected by the system during daylight hours (Struhsaker 1973, Amesbury 1975, Reid et al. 1991, Reid 1994). Sampling was conducted during first and last light to measure the temporal boundaries of the community and to measure background levels of density and relative abundance of other organisms. Sampling occurred during all phases of the moon although samples within each phase were not equally distributed, eliminating the ability to test for moon phase as a factor. Twenty sampling locations were selected in shallow, inshore waters, 20 to $50 \mathrm{~m}$ in depth and 1.0 to $1.3 \mathrm{~km}$ from shore. Twenty sites in deeper, offshore waters defined as 175 to $200 \mathrm{~m}$ in depth and 2.8 to $3.0 \mathrm{~km}$ from shore were also chosen (Fig. 1). Within each depth category, sampling sites were divided equally into those that had relatively flat, homogenous substrates and those that were 3-dimensionally complex and heterogeneous as determined by the Oahu Coastal Zone Atlas (Aecos for the US Army Corps of Engineers 1981). Sampling sites had the same type of bottom topography for at least $150 \mathrm{~m}$ in any direction and were at least $300 \mathrm{~m}$ from any other site. Each site was sampled twice during each time period (18:00-19:00, 21:00-22:00, 00:00-01:00, 03:00-04:00, 06:00-07:00 h) for a total of 10 samples at each site. No

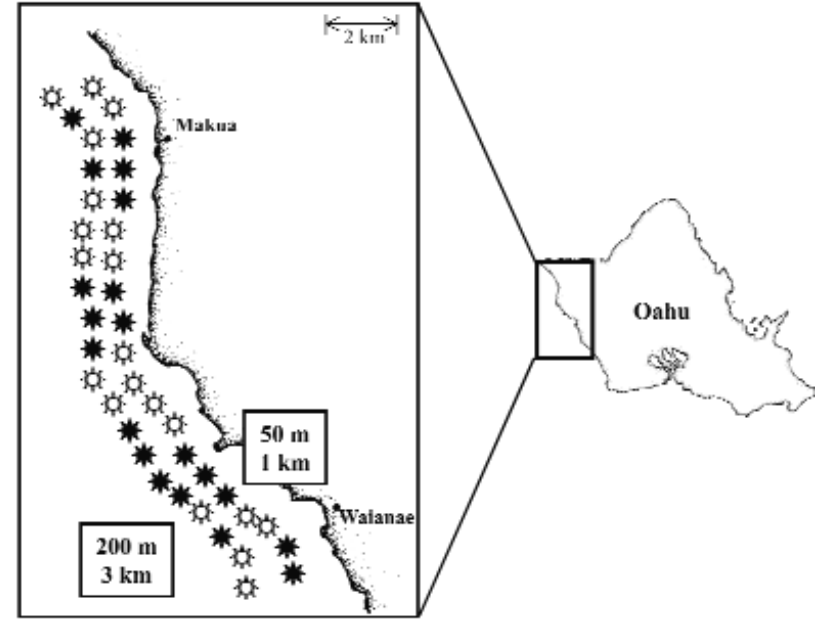

Fig. 1. Sampling locations off the coast of Waianae, Oahu, Hawaii. Sampling was conducted using a $10 \mathrm{~m}$ boat traveling at $2.6 \mathrm{~m} \mathrm{~s}^{-1}$ (5 knots) over the bottom. Circular transects $100 \mathrm{~m}$ in diameter were conducted for $1 \mathrm{~h}$, at $3 \mathrm{~h}$ intervals starting $1 \mathrm{~h}$ before dusk $(18: 00 \mathrm{~h})$ and ending $1 \mathrm{~h}$ after dawn $(06: 00 \mathrm{~h})$. An average of 12 transects could be sampled each hour. Half of the sampling sites were located in $50 \mathrm{~m}$ of water, $1 \mathrm{~km}$ from shore, the other half were located $3 \mathrm{~km}$ from shore in $200 \mathrm{~m}$ of water. Half of each of the shallow and deep sites had 3-dimensionally complex bottoms (filled symbols) and half had flat bottoms (open symbols). Each site was sampled twice during each sampling interval (total $n=400$ )

site was sampled more than once on a given night. Relative abundance and density data were analyzed using a nested factorial ANOVA with bottom type and distance/depth as fixed factors nested within time. With this design, the a priori power (variance $=1200,0.15$ effect, total $n=400, \alpha=0.05$ ) was 0.86 . Analysis of variance calculations were made using a customized Excel routine based on the equations of Underwood (1997) for a nested factorial design with 2 orthogonal and 1 nested variable. Differences found in ANOVAs were also analyzed using 2-tailed $t$-tests corrected for multiple comparisons using the Bonferroni method. Stat View for the Macintosh was used to calculate $t$-statistics.

Kona. The Kona coast of the Big Island of Hawaii was surveyed from the $50 \mathrm{~m}$ National Oceanic and Atmospheric Administration ship, 'Townsend Cromwell', on November 10 to 15, 1999. Sampling occurred during new and first quarter phases of the moon. Transects off the Kona coast were $9.3 \mathrm{~km}$ ( $5 \mathrm{n}$ mile) long and oriented parallel to shore. Two of the transects were approximately 2.8 to $3.0 \mathrm{~km}$ from shore while 3 were located 1.0 to $1.3 \mathrm{~km}$ from the shoreline. Because of differences in bottom topography off the Kona coast compared with the Waianae, Oahu coast, distance from shore and depth are not correlated factors. The average depth for each inshore transect was similar to the 
average depth of the offshore transect located north, providing a means of separating the effects of depth and distance from that of shore (Fig. 2). Each transect was surveyed for $1 \mathrm{~h}$ at 21:00, 24:00, and 03:00 $\mathrm{h}$ while traveling at $2.6 \mathrm{~m} \mathrm{~s}^{-1}$ ( 5 knots) over the bottom. For statistical purposes, each transect was broken into 30,

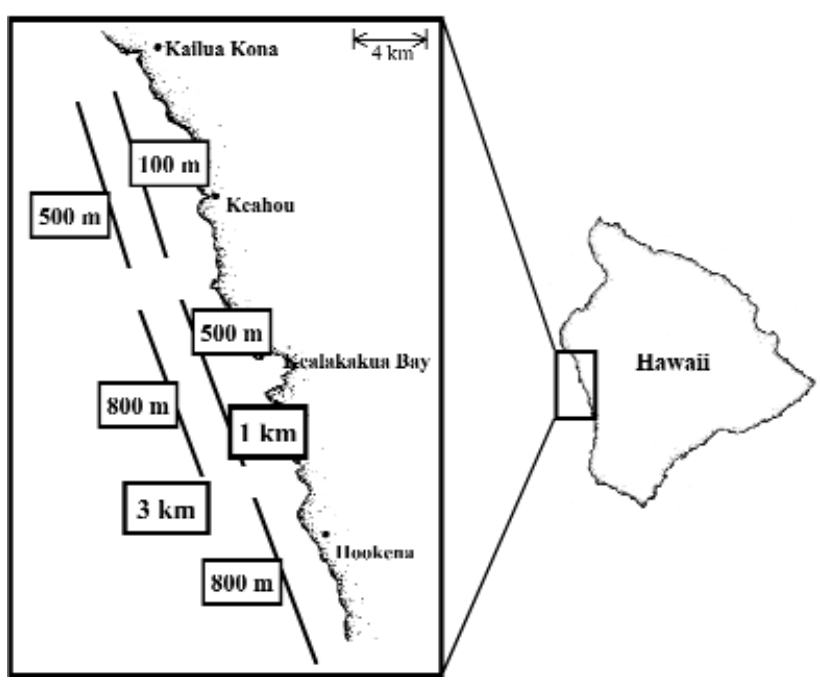

Fig. 2. Sampling locations off the Kona coast of the Big Island of Hawaii. Five, $9.3 \mathrm{~km}$ long transects were surveyed from the $50 \mathrm{~m}$ NOAA ship 'Townsend Cromwell', $2 \mathrm{~h}$ of the transects were $3 \mathrm{~km}$ from shore; 3 were located $1 \mathrm{~km}$ from shore. Because of differences in bottom topography off this coast, sites could not be identified by depth. Each inshore transect had the same average depth as the offshore transect to its north. Each transect was sampled once at 21:00 to 22:00 h, 00:00 to 01:00 h, and 03:00 to 04:00 h. For statistical purposes, each transect was broken up into 30, $300 \mathrm{~m}$ long segments (total $\mathrm{n}=450$ )
$300 \mathrm{~m}$ long segments, the same length as the circumference of the circular transects in Waianae. Relative abundance and density data from each transect was compared using a nested factorial ANOVA for depth and distance from shore as fixed factors nested in time. A second nested factorial ANOVA was used to assess the effect of current. Distance was a fixed factor, current a random factor, both nested in time. Note that this is an unbalanced design as there is no offshore site with a depth of $100 \mathrm{~m}$. This is dealt with following the method of Shaw \& Mitchell-Olds (1993). The large sample sizes limits the problems associated with the missing samples. While the $300 \mathrm{~m}$ long samples cannot be considered independent, this method for stratification of long transects has been advocated by some authors (see a review in Simmonds et al. 1992). To test the impact of this assumption on this data, ten $300 \mathrm{~m}$ long transects were randomly selected from each transect and compared by the same techniques. This was repeated 5 times. In addition, to assess the consistency of the patterns observed in Waianae, the predictions of five models (Fig. 3; see also Table 4) for the effect of time on relative abundance and density were compared to the data obtained in Kona using 2-tailed $t$ tests corrected for multiple comparisons using the Bonferroni method.

Data collection. Acoustic data were collected using a Computrol, Tournament Master Fishfinder NCC 5300 modified to read directly into a laptop computer. The envelope of the echo was digitized at a sampling rate of $5 \mathrm{kHz}$ using National Instruments DAQcard AI-16E-4 off Waianae, and a Rapid System R1200 off Kona. Data acquisition was triggered by the outgoing signal and was collected in blocks of 1024 points, rep-
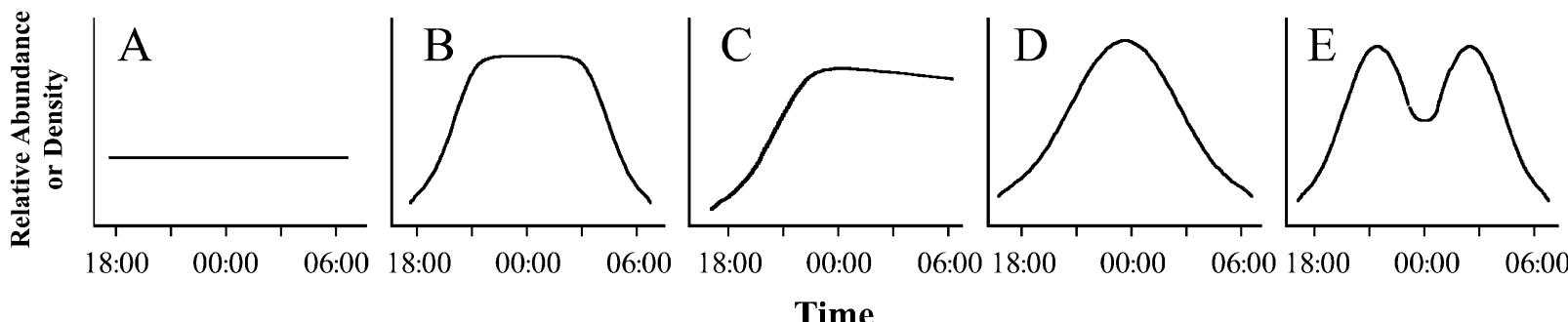

Time

Fig. 3. Models for abundance and density patterns of mesopelagic organisms at a single point as a function of time. (A) No input of organisms at this location; no migration; this would be expected were organisms deeper than the maximum range of the echosounder or if organisms were not present. (B) Input of organisms increases until maximum abundance or density is attained at approximately 21:00 $\mathrm{h}$; abundance or density of organisms stays relatively constant until the organisms migrate out of the location again; this could be an indication of horizontal or vertical migration into the area with a reciprocal migration out of the area. (C) Input of organisms increases until they reach a maximum abundance and organisms do not migrate out of the location again; losses are accounted for by consumption of organisms; this could indicate that organisms are vertically migrating but are not returning to deep water, or that organisms are migrating inshore but are unable to migrate offshore again. (D) Abundance of organisms constantly increases until it reaches a maximum and then decreases as the organisms migrate out of the area; this model is derived from the Shallow/Inshore Waianae sites. (E) Abundance of organisms is bimodal. Organisms migrate in and out of the area twice during a single night; this could indicate 2 vertical migrations or a 2-way horizontal migration; this model is derived from the Deep/Offshore Waianae sites 
resenting $156 \mathrm{~m}$ of vertical space. The echosounder uses a $200 \mathrm{kHz}$ outgoing signal with a pulse length of $130 \mu \mathrm{s}$. The transducer's signal is a downward pointing, $10^{\circ}$ cone. The transducer was mounted directly to the transom of the vessel during the Waianae data collection. During the Kona cruise, the transducer was mounted on a towfish that was attached to the boom of the 'Townsend Cromwell'. The towfish 'flew' $0.3 \mathrm{~m}$ beneath the surface of the water, regardless of the ship's speed over water. Beaufort Sea State was 0 to 2 during all sampling.

Ancillary data. During 3 evenings of the Kona cruise, MOCNESS $\left(1 \mathrm{~m}^{2}\right.$ opening, $0.333 \mathrm{~mm}$ mesh multiple opening and closing net environmental sensing system) trawls were conducted at 01:00 to $02: 30,3.0$ to $3.5 \mathrm{~km}$ from the shoreline in approximately the same area as the offshore sites. The MOCNESS trawl collected samples at $25 \mathrm{~m}$ depth intervals, starting at $200 \mathrm{~m}$ and ending at the surface. Acoustic sampling with the echosounder was conducted simultaneously. CTD (conductivity, temperature, depth) casts were conducted at the beginning and end of each acoustic transect. The CTD also measured dissolved oxygen and fluorescence. Ocean current velocities in the upper 200 to $250 \mathrm{~m}$ of the water column were observed using a shipboard RD Instruments acoustic Doppler current profiler (ADCP) operating at $150 \mathrm{kHz}$. The resulting current patterns were placed in one of 6 categories for analysis of the effect of current on observed patterns of relative abundance: $>75 \%$ of water column moving toward shore, $>75 \%$ of water column moving away from shore, $>50<75 \%$ of water column moving toward shore, $>50<75 \%$ of water column moving away from shore, current nearly equal in both directions, and $<10 \%$ of water column moving onshore-offshore.

A remotely operated drop video camera with a surface-controlled light was deployed $3 \mathrm{~km}$ from shore between 23:30 and 00:00 $\mathrm{h}$ one night while acoustic data were collected simultaneously. The camera was lowered, with the light off, in $5 \mathrm{~m}$ increments to a final depth of $40 \mathrm{~m}$. At each incremental depth, the camera was allowed to stand for 5 min then the camera was turned on, followed by the light. Video recording took place for $15 \mathrm{~s}$ and then the light was turned off and the camera was lowered a further $5 \mathrm{~m}$. The process was repeated for the camera's ascent.

Data analysis. The relative abundance of organisms was calculated as the percent of the outgoing signals that returned with organisms present (MacLennan \& Simmonds 1992). This is analogous to catch-per-uniteffort:

$$
R A=100\left(E_{+} / S_{\mathrm{t}}\right)
$$

where $R A$ is relative abundance, $E_{+}$is the number of returning echoes that contain organisms, and $S_{\mathrm{t}}$ is the total number of outgoing signals.
Numerical density $(\rho)$, in organisms $\mathrm{m}^{-3}$ was calculated with an echo energy integration technique, using the equation (MacLennan \& Simmonds 1992):

$$
\rho=[C g /(\psi<\sigma>)] E
$$

where $C$ is the on-axis sensitivity of the echosounder, $g$ is the time varying gain correction, $\psi$ is the equivalent beam angle, $\langle\sigma\rangle$ is the average backscatter cross-section, and $E$ is the mean energy flux density of the echo.

The values for the product of the on-axis sensitivity and time-varying gain correction $(C g)$ were determined by measuring the response of the echosounder when receiving echoes from calibrated targets. Two calibrated targets, a $7.62 \mathrm{~cm}$ solid steel sphere and a $15.24 \mathrm{~cm}$ diam. water-filled sphere, were used. The target strengths of both spheres were measured in a tank, resulting in values that were within $2 \mathrm{~dB}$ of the theoretical values expressed in Urick (1983). The response of the echosounder to the calibrated spheres was then determined by lowering the targets to a depth of $156 \mathrm{~m}$ while the echosounder continuously recorded the echoes. The depth of the sphere was observed on the echosounder while the envelope of the signal, the voltage of the outgoing signal, and the length of line let out were recorded. The sphere was lowered underneath the vessel in a protected area with few currents. Although this does not guarantee that the sphere was lowered in the center of the transducer's beam, the diameter of the area covered by the beam at $156 \mathrm{~m}$ (the maximum range of the system) is $28 \mathrm{~m}$. If the sphere was anywhere within this range, its echo would be within $3 \mathrm{~dB}$ of an echo returned from the center of the beam. Comparing the amount of line let out with the actual depth of the sphere revealed that, at $156 \mathrm{~m}$, the sphere was less than $5 \mathrm{~m}$ away from the center of the beam, considerably less than the $14 \mathrm{~m}$ radius of the beam. This suggests that off-axis measurement of the sphere introduced considerably less than $3 \mathrm{~dB}$ of error into the time-varying gain correction.

The equivalent beam angle, $\psi$, was obtained from the theoretical equation for a planar circular disk transducer (Urick 1983) and was within 5\% of the value the manufacturer measured for the transducer. The threshold of the system was measured by measuring the returns from solid steel spheres of known target strength in a tank. This method is identical to that used to calibrate the $C g$ product, however the spheres were much smaller, the largest being $1.1 \mathrm{~cm}$. The size of the calibrated sphere was decreased in $0.2 \mathrm{~cm}$ increments until the sphere could no longer be detected with the system. An analysis of a regression between the voltage of the received echo from the sphere and the target strength of the sphere resulted in a threshold estimate of $-63 \mathrm{~dB}$. 
The average backscatter cross-section $<\sigma\rangle$ is related to target strength (TS) by

$$
<\sigma>=4 \pi 10^{(T S / 10)}
$$

Using the values for $C g$ as a function of depth, the target strength of the echoes returned from scatterers in the mesopelagic layer $\left(T S_{\mathrm{mbc}}\right)$ was determined from the equation

$T S_{\mathrm{mbc}}=20 \log \left(V_{\text {env }} / V_{\text {calibrated }}\right)+T S_{\text {calibrated }}$

where $V_{\text {env }}$ is the voltage received by the echosounder from scatterers at a given depth, $V_{\text {calibrated }}$ is the voltage of the echo a calibrated sphere would produce at the same depth, and $T S_{\text {calibrated }}$ is the known target strength of the calibrated sphere. Using this equation, the mode target strength of all returns was $-37 \mathrm{~dB}$. The mean target strength was $-42 \mathrm{~dB}$. To conservatively estimate density, the mode target strength was used to calculate $<\sigma>$. It is important to realize that this target strength does not represent returns from individual organisms, nor is it an attempt to measure the in situ target strength of individual scatterers. This target strength value is used to conservatively (underestimate) the density of the community and is in agreement with target strengths of live individual animals from the community measured in a tank (Benoit-Bird \& Au 2001).

The position, depth, and signal strength data from the echosounder were analyzed in ArcView Geographic Information System with 3-D Analyst in order to determine the vertical distribution of mesopelagic organisms (Fig. 4). In areas with a vertically continuous distribution of returns, a defined layer, the maximum and minimum depth of returns were recorded for each $5 \mathrm{~m}$ of horizontal distance. These were then averaged according to factors determined to be significant in the ANOVAs to obtain the maximum and minimum depth of the layer, and consequently its vertical distribution.

\section{RESULTS}

\section{Waianae}

The relative abundance of organisms off the Waianae coast varied from virtually zero to nearly $100 \%$ (Fig. 5). At around 18:00 and 06:00 $\mathrm{h}$, the relative abundance never exceeded $16 \%$, between $21: 00$ and $22: 00 \mathrm{~h}$ the maximum relative abundance was $72 \%$. At 00:00 to $01: 00 \mathrm{~h}$, the maximum relative abundance neared $100 \%$, while at 03:00 to 04:00 h the maximum was $62 \%$.
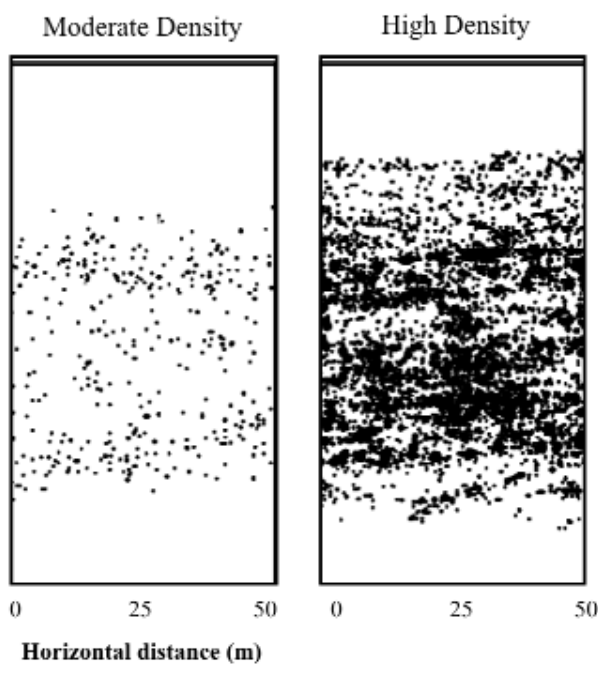

Fig. 4. Samples of acoustic data graphed in ArcView. Each graph repreents a horizontal distance of $50 \mathrm{~m}$ and a vertical depth of $100 \mathrm{~m}$; each point the graphs represents a single signal returned to the echosounder. Left of organisms ( 0 organisms $\mathrm{m}^{-3}$ ), common during y evening and pre-dawn; center graph shows moderate density of organisms (10 organisms $\mathrm{m}^{-3}$ ), common for many times and locations; right $y$ of organisms (115 organisms $\mathrm{m}^{-3}$ ), seen only inshore near midnight

An ANOVA on relative abundance for the effects of distance/depth, bottom type, and sampling time revealed significant effects of distance/depth $(p<0.001)$ and bottom type $(p<0.05)$ and for each of these effects nested within time $(p<0.001$ and $p<0.05$ respectively; Table $1)$. There were no significant interactions ( $p>0.05)$. The general pattern of relative ab-undance with respect to time was different at inshore/shallow and offshore/ deep sites. The in-shore/shallow sites showed a unimodal, bell-shaped curve with a single peak in relative abundance near midnight. The offshore/deep sites had a bimodal distribution with peaks at around 21:00 and

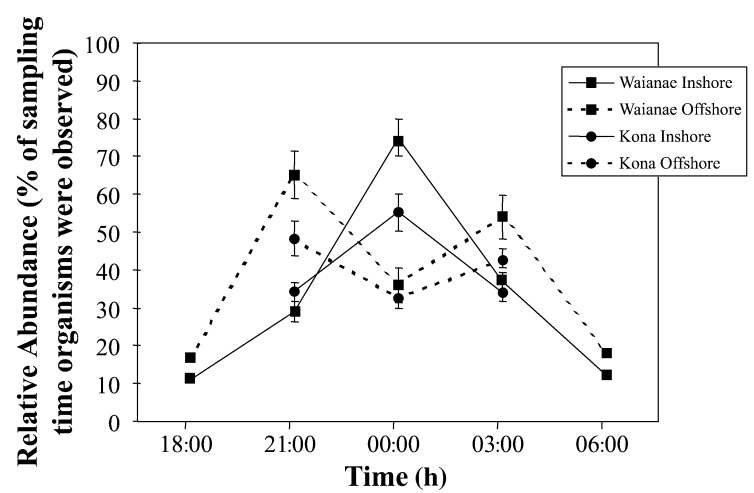

Fig. 5. Mean relative abundance of mesopelagic organisms as a function of sampling time and distance from shore. Error bars represent standard error of the mean. For both Waianae and Kona there is a significant effect of distance from shore and sampling time on relative abundance 
03:00 h. The relative abundance of organisms at the inshore/shallow sites around midnight was also greater than the relative abundance in the offshore/deep sites at any time.

Differences in relative abundance due to bottom type, found to be significant in the nested factorial ANOVA, were analyzed using corrected post-hoc $t$ tests. Only at the 00:00 to 01:00 h and 03:00 to 04:00 h sampling intervals were differences in relative abundance over 3-dimensional versus flat bottoms found to be significantly different. In both inshore/shallow and offshore/deep sites, the relative abundance of organisms at 00:00 to $01: 00 \mathrm{~h}$ was significantly

higher over 3-dimensional substrates than over flat substrates $(\mathrm{p}<0.05)$. At 03:00 to 04:00 h, the relative abundance was higher over flat bottoms than 3-dimensional ones ( $p<0.05$ ) in both sampling locations (Fig. 6).

Estimates of the density of organisms off the Waianae coast varied from zero to 1800 organisms $\mathrm{m}^{-3}$. The mean density of the entire water column, or the top $156 \mathrm{~m}$ if the depth of the water exceeded the range of the echosounder, varied from zero to 23 organisms $\mathrm{m}^{-3}$ (Fig. 7). Maximum density occurred at midnight, while minimums were at 18:00 to $19: 00 \mathrm{~h}$ and 06:00 to 07:00 h. A nested factorial ANOVA revealed a significant distance/depth effect $(p<0.05)$ but no effect of bottom type $(p>0.05)$. Time was also a significant factor $(p<0.005)$. There were no significant interactions (Table 1 ). The patterns of density as a function of time off Waianae appeared similar to the patterns in relative abundance off Waianae. Inshore transects showed a unimodal, bell-
Inshore

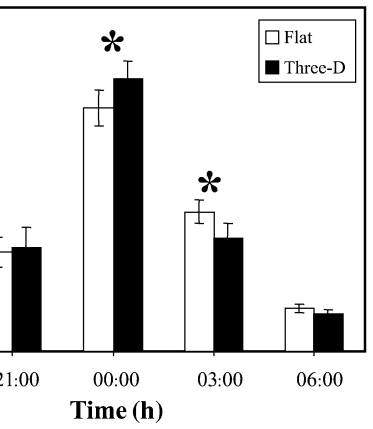

Offshore

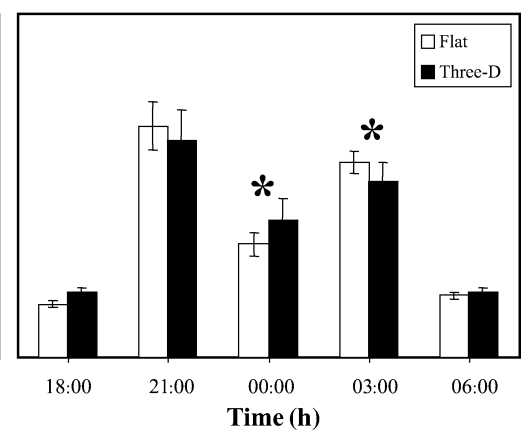

Fig. 6. Relative abundance of mesopelagic organisms at Waianae inshore and offshore sites as a function of sampling time and bottom type. Bottom substrates were either 3 ences in abundance: at midnight, 3-dimensionally complex bottoms displayed higher marked with asterisk. Error bars represent standard error of the mean
mative abundance while the opposite was true at 03:00 h. Significant re

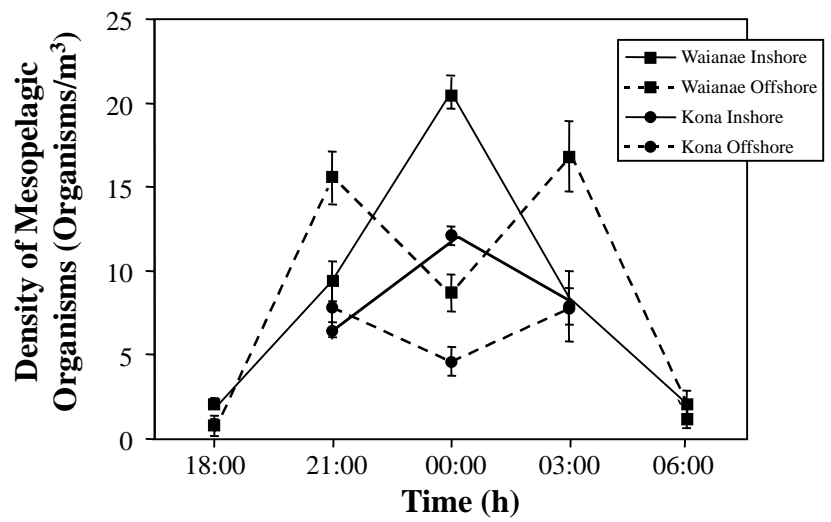

Fig. 7. Mean density, calculated by echo energy integration of mesopelagic organisms as a function of sampling time and distance from shore. Error bars represent standard error of the mean. For both Waianae and Kona there is a significant effect of distance from shore and sampling time

Table 1. Results of nested factorial ANOVAs for relative abundance and density of mesopelagic organisms off the Waianae coast of Oahu. The design has 2 orthogonal factors, distance from shore (1 and $3 \mathrm{~km}$ ) and bottom type (3-dimensional or flat), which are nested within 5 sampling times $(18: 00,21: 00,00: 00,03: 00,06: 00 \mathrm{~h})$. Note, distance from shore could easily be labeled depth, as these 2 factors are not independent. ns: not significant

\begin{tabular}{|c|c|c|c|c|c|c|c|}
\hline \multirow{2}{*}{$\overline{\text { Source of variation }}$ Rel } & \multicolumn{3}{|c|}{ Relative abundance } & \multirow[b]{2}{*}{ Source of variation } & \multirow{2}{*}{$\begin{array}{r}\text { Density } \\
\mathrm{df}\end{array}$} & \multirow[b]{2}{*}{ SS } & \multirow[b]{2}{*}{$\mathrm{p}$} \\
\hline & df & SS & $\mathrm{p}$ & & & & \\
\hline Distance & 1 & 52457225 & $<0.001$ & Distance & 1 & 3286978 & $<0.05$ \\
\hline Bottom Type & 1 & 1164109 & 0.05 & Bottom Type & 1 & 24687 & ns \\
\hline Distance $\times$ Bottom & 1 & 22178 & ns & Distance $\times$ Bottom & 1 & 54387 & ns \\
\hline Time(Distance) & 5 & 91287545 & $<0.001$ & Time(Distance) & 5 & 6538185 & $<0.005$ \\
\hline Time(Bottom) & 5 & 5149126 & $<0.05$ & Time(Bottom) & 5 & 14552 & ns \\
\hline Time $($ Distance $\times$ Bottom $)$ & 5 & 203313 & ns & Time(Distance $\times$ Bottom) & 5 & 35415 & ns \\
\hline Residual & 380 & 302422 & & Residual & 380 & 76518 & \\
\hline Total & 398 & & & Total & 398 & & \\
\hline
\end{tabular}


shaped distribution of mean density as a function of sampling time with a maximum around midnight, while offshore sites had a bimodal distribution with peaks at 21:00 to 22:00 $\mathrm{h}$ and 03:00 to 04:00 $\mathrm{h}$ and a trough at midnight. The density of organisms at the inshore sites around midnight also had the highest density of organisms, greater than either maximum of the offshore sites.

\section{Kona}

The results of statistical tests on Kona relative abundance and density data were not altered by any of randomly subsampled iterations of the transect versus the statistical results using all subsamples of the transect. Only the statistics on the entire transects are presented here. The relative abundance of organisms off the Kona coast of the Big Island of Hawaii varied from virtually zero to nearly $70 \%$ (Fig. 5). At 21:00 to $22: 00 \mathrm{~h}$ and 03:00 to $04: 00 \mathrm{~h}$ the maximum relative abundance measures were 53 and $46 \%$, respectively. The maximum relative abundance at 00:00 to 01:00 h was $69 \%$. A nested factorial ANOVA revealed that distance from shore significantly affected relative abundance $(\mathrm{p}<0.01$, $\mathrm{p}<0.05)$, but depth did not ( $p>0.05)$. There were no significant interactions (Table 2).

Estimates of the density of organisms off the Kona coast varied from zero to $700 \mathrm{~m}^{-3}$. The mean density of the entire water column, or the surface to $156 \mathrm{~m}$ if the depth of the water exceeded the range of the echosounder, varied from zero to 15 organisms $\mathrm{m}^{-3}$ (Fig. 7). As off Waianae, the maximum density occurred around midnight; however, because of the bimodal distribution of density at offshore sites and because 18:00 to 19:00 h and 06:00 to 07:00 h were not sampled, the minimum also occurred at midnight. A nested factorial ANOVA revealed that distance had a significant effect $(\mathrm{p}<0.05)$, as did time $(\mathrm{p}<0.05)$; depth, however, did not $(\mathrm{p}>0.05)$. There were no significant interactions (Table 2). To assess the role of currents in the relative abundance and density of organisms, depth, determined not to be a significant factor, was removed from the analysis and the current category was added (Table 3 ). The current pattern over the upper 200 to $250 \mathrm{~m}$ of the water column at each location was not a significant factor $(\mathrm{p}>0.05)$.

Table 2. Results of nested factorial ANOVAs for relative abundance, and density of mesopelagic organisms off the Kona coast of the Big Island of Hawaii. The design has 2 orthogonal factors, distance from shore (1 and $3 \mathrm{~km})$ and depth $(100,500,800 \mathrm{~m})$, nested within 3 sampling times $(21: 00,00: 00,03: 00 \mathrm{~h})$. Note that design is not balanced: for shallowest depth $(100 \mathrm{~m})$ there are

no samples $3 \mathrm{~km}$ from shore. Residual sums of squares were calculated after the methods of Shaw \& Mitchell-Olds (1993)

\begin{tabular}{|c|c|c|c|c|c|c|c|}
\hline$\overline{\text { Source of variation }} \mathrm{Re}$ & \multicolumn{3}{|c|}{ Relative abundance } & Source of variation & $\begin{array}{r}\text { Density } \\
\mathrm{df}\end{array}$ & SS & $\mathrm{p}$ \\
\hline Distance & 1 & 14365468 & $<0.01$ & Distance & 1 & 5456451 & $<0.05$ \\
\hline Depth & 2 & 42387 & ns & Depth & 2 & 32451 & ns \\
\hline Distance $\times$ Depth & 2 & 164824 & ns & Distance $\times$ Depth & 2 & 54499 & ns \\
\hline Time(Distance) & 3 & 3573554 & $<0.05$ & Time(Distance) & 3 & 4754458 & $<0.05$ \\
\hline Time(Depth) & 6 & 78573 & ns & Time(Depth) & 6 & 62755 & ns \\
\hline Time (Distance $\times$ Depth) & 6 & 687114 & ns & Time(Distance $\times$ Depth) & 6 & 72645 & ns \\
\hline Residual & 493 & 1289443 & & Residual & 493 & 1095204 & \\
\hline Total & 512 & & & Total & 513 & & \\
\hline
\end{tabular}

Table 3. Results of nested factorial ANOVAs for relative abundance and density of mesopelagic organisms off the Kona coast of the Big Island of Hawaii. Depth has been removed as a factor and replaced by current category. Current patterns were categorized into 1 of 6 types and then the significant factor, distance, was reanalyzed with respect to current

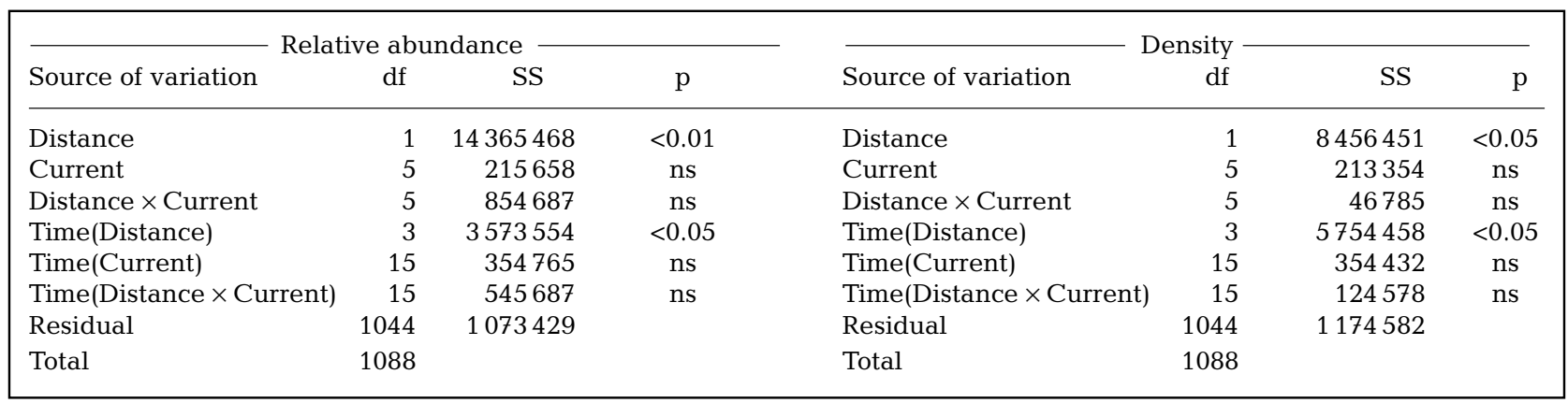


To compare patterns observed off the Waianae coast of Oahu with results obtained using different sampling methods off the Kona coast of the Big Island, models were created for the patterns of relative abundance and density observed in Waianae, as were several alternative models (Fig. 3). The relative abundance and density trends were tested with corrected $t$-tests and compared to the predictions of the various models (Table 4). For Transects 1 and 3, the relative abundance of organisms was significantly greater at 21:00 to 22:00 h than at 00:00 to 01:00 $\mathrm{h}(\mathrm{p}<0.05)$. The relative abundance of organisms at midnight compared to $03: 00$ to $04: 00 \mathrm{~h}$ was significantly lower for both Transects 1 and 3 $(\mathrm{p}<0.05)$. The same differences were observed in density estimates for Transects 1 and 3 for both time comparisons $(\mathrm{p}<0.05)$. These differences fit the predictions of Model E, the pattern observed in the offshore/deep Waianae sites. Transects 2, 4 and 5 had significantly lower relative abundance levels at $21: 00$ to $22: 00 \mathrm{~h}$ compared to 00:00 to 01:00 h $(\mathrm{p}<0.05)$, and significantly higher relative abundance levels at midnight compared with 03:00 to 04:00 $\mathrm{h}(\mathrm{p}<0.05)$. The same pattern is seen in the density data $(\mathrm{p}<0.05)$. These differences are consistent with the predictions of Model D, the pattern observed in the inshore/shallow Waianae sampling locations. The data from Kona did not fit the predictions of any of the alternative models (Table 5).

\section{Vertical distribution}

The variation in the vertical distribution of organisms was small between locations within a sampling category at each sampling time (Fig. 8). Off both Waianae and
Table 4. Predictions of the 5 models of relative abundance and density shown in Fig. 3. Direction of the predicted relationships between samples taken at midnight and at 21:00 and 03:00 $\mathrm{h}$ are shown. Note that Model A and B cannot be separated simply by comparisons between 21:00, 00:00, and 03:00 $\mathrm{h}$

\begin{tabular}{|ccc|}
\hline \multirow{2}{*}{ Model } & \multicolumn{2}{c|}{ Predictions } \\
& $21: 00$ vs 00:00 h & $00: 00$ vs 03:00 h \\
\hline A & $=$ & $=$ \\
$\mathrm{B}$ & $=$ & $=$ \\
$\mathrm{C}$ & $<$ & $=$ \\
$\mathrm{D}$ & $<$ & $>$ \\
$\mathrm{E}$ & $>$ & $<$ \\
\hline
\end{tabular}

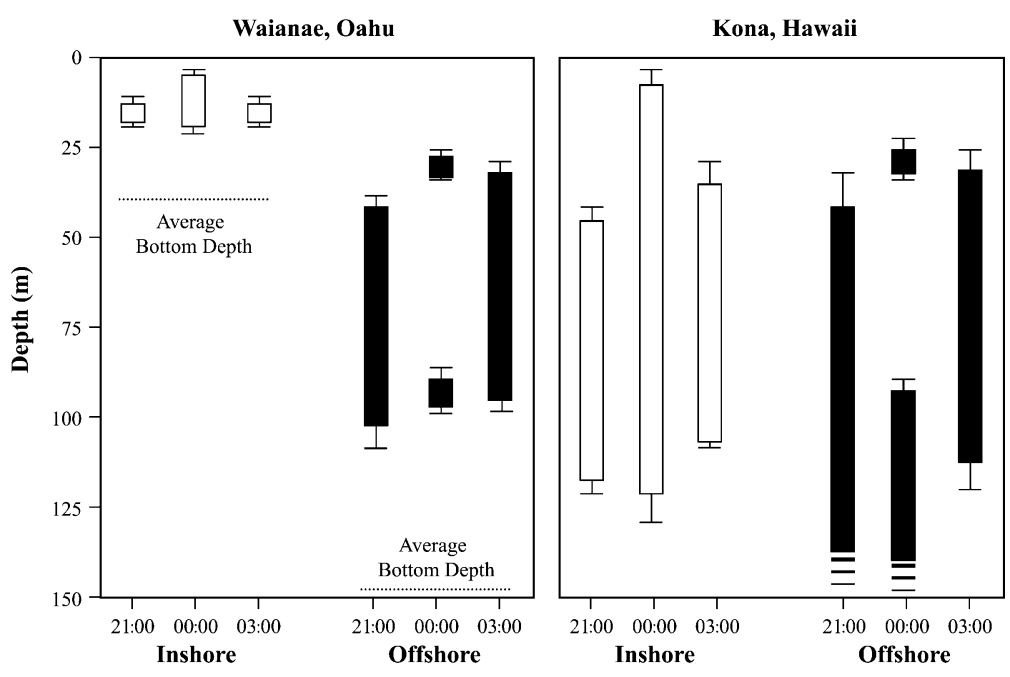

Fig. 8. Vertical distribution of mesopelagic boundary organisms for Waianae, and Kona sites Open bars: inshore sites; black bars: offshore sites. Average depths of Waianae sites are shown by dotted horizontal lines. Maximum depth of $y$-axis represents maximum range of the echosounder system. The average depth off Kona exceeds the maximum range of the fishfinder. In both Kona and Waianae, offshore sites show a split distribution at midnight. Error bars represent standard deviation of the mean for both the minimum and maximum depths of organisms

Table 5. Results of 2-tailed $t$-tests, corrected for multiple comparisons using Bonferonni method. Relative abundance and density are shown for each Kona coast transect. Direction of significant differences are shown, followed by $p$ values in parentheses. The 'Model' column shows the model whose predictions the observed trend fits. The results suggest that the patterns observed off the Waianae coast of Oahu are also present off Kona. They also indicate that these patterns are driven by distance of sampling location from shore, rather than average depth

\begin{tabular}{|c|c|c|c|c|c|c|}
\hline \multirow{2}{*}{ Transect } & \multicolumn{3}{|c|}{ Relative abundance } & \multicolumn{3}{|c|}{ Density } \\
\hline & $21: 00$ vs $00: 00 \mathrm{~h}$ & 00:00 vs 03:00 h & Model & $21: 00$ vs $00: 00 \mathrm{~h}$ & 00:00 vs 03:00 h & Model \\
\hline 1 & $>(p<0.05)$ & $<(\mathrm{p}<0.05)$ & E & $>(p<0.05)$ & $<(\mathrm{p}<0.05)$ & E \\
\hline 2 & $<(\mathrm{p}<0.01)$ & $>(\mathrm{p}<0.05)$ & $\mathrm{D}$ & $<(\mathrm{p}<0.05)$ & $>(\mathrm{p}<0.05)$ & $\mathrm{D}$ \\
\hline 3 & $>(\mathrm{p}<0.05)$ & $<(\mathrm{p}<0.05)$ & $\mathrm{E}$ & $>(p<0.01)$ & $<(\mathrm{p}<0.05)$ & $\mathrm{E}$ \\
\hline 4 & $<(\mathrm{p}<0.01)$ & $>(\mathrm{p}<0.05)$ & $\mathrm{D}$ & $<(\mathrm{p}<0.05)$ & $>(p<0.01)$ & $\bar{D}$ \\
\hline 5 & $<(\mathrm{p}<0.001)$ & $>(\mathrm{p}<0.01)$ & $\mathrm{D}$ & $<(\mathrm{p}<0.01)$ & $>(p<0.01)$ & $\mathrm{D}$ \\
\hline
\end{tabular}


Kona, the layer was never less than $3 \mathrm{~m}$ from the surface. This close approach to the surface only occurred at midnight at inshore sites. The minimum distance of the layer from the surface around 21:00 and 03:00 h at Waianae's inshore sites was $10 \mathrm{~m}$, while in Kona's inshore sites it was 40 and $30 \mathrm{~m}$, respectively. The minimum distance of the layer from the surface at the shallow Kona sites around midnight was $6 \mathrm{~m}$, the shallowest observed there. The maximum distance of the layer from the surface varied little with time. Inshore at Waianae, the layer's maximum distance from the surface ranged from 18 to $21 \mathrm{~m}$, regardless of time. At Kona's inshore transects, the maximum distance of the layer from the surface ranged from 112 to $130 \mathrm{~m}$, with the layer having the greatest vertical range during the midnight sampling interval. The vertical range of organisms off Waianae was small compared to that of Kona. The bottom of the layer never came closer to the sea floor than $11 \mathrm{~m}$ off Waianae. The bottom was not within the range of the echosounder in most of the inshore Kona sites.

The vertical distribution of organisms at offshore sites was not as simple. The maximum depth of organisms did not vary much along each coastline. Off Waianae, the layer's maximum depth ranged from 100 to $110 \mathrm{~m}$. Off Kona, the layer's maximum depth ranged from $122 \mathrm{~m}$ to at least $156 \mathrm{~m}$, the maximum range of the echosounder system. It was impossible to determine if the layer's range exceeded this depth. The minimum depth of the layer in the offshore sites of Waianae varied from 28 to $40 \mathrm{~m}$, while off Kona it ranged from 25 to $38 \mathrm{~m}$. The shallowest depths of the layer were observed at midnight off both Waianae and Kona. The layer was not vertically continuous at the offshore sites of Waianae or Kona. Two distinct layers were visible, the shallower layer had an average vertical range of less than $15 \mathrm{~m}$ in both locations. The deeper layer had a similar vertical range, less than $15 \mathrm{~m}$, off Waianae. The deeper layer off Kona had a range of over $40 \mathrm{~m}$. Off both islands, the upper limit of the deeper layer was approximately $90 \mathrm{~m}$.

\section{Ancillary data}

MOCNESS trawls were conducted on 3 nights during the Kona cruise in approximately the same area as the offshore sites. The nets sampling 100 to 150 m captured a total of 29 fishes from the family Myctophidae, 8 fishes from various other mesopelagic families, and 29 of the shrimp Sergia fulgens. All these organisms were members of the boundary community as defined by Reid et al. (1991). A total of 4 fishes not defined as mesopelagic boundary community organisms were also captured in the 100 to 150 m nets. The 25 to $50 \mathrm{~m}$ net caught 3 fishes from the family Myctophidae, all species defined as boundary species, and several siphonophonores. The sample size does not permit any strong statements to be made about differences between the 2 layers observed acoustically; however, the lower layer seems to contain many more shrimp than the upper layer.

Nets sampling depth ranges where the boundary layer was not detected acoustically caught a wide range of organisms, including gelatinous organisms such as salps, siphonophores, and pyrosomes, larvae of many species of crustaceans, pelagic decapod crustaceans, various larval fishes, and 2 fishes not defined as boundary community species. Acoustic reflections were not observed from these organisms, probably because their target strengths were lower than the system's $-63 \mathrm{~dB}$ threshold in the case of the planktonic animals, or their densities were too low in the case of the fishes.

The video recording revealed that few micronektonic organisms were present until the camera reached a depth of $25 \mathrm{~m}$, the top of the layer observed acoustically. Myctophids were the only organisms observed correctly focused in the camera. Similar organisms were observed to $40 \mathrm{~m}$. The resolution of the camera was limited and the fishes moved away rapidly when the light was turned on. However, in the first few frames following each trigger of the light, the number of myctophids visible was calculated to be between 24 and 31 .

\section{DISCUSSION}

Sampling the mesopelagic boundary community using acoustic techniques provided several important advantages over traditional techniques. First, sampling could be conducted much more closely to shore and in much shallower waters, without fear of bottom collisions. Second, large spatial areas could be sampled quickly, with high spatial resolution. Third, information about vertical distribution could be obtained for the water column down to $156 \mathrm{~m}$ simultaneously. There was no need for multiple, separate samples as would be necessary to separate vertical distribution of densities using trawling techniques. Fourth, areas could easily be re-sampled at various times to allow discrimination of temporal factors. Reid et al. (1991) lumped data from all trawls between 30 min after sunset and $1 \mathrm{~h}$ before sunrise. The results of the present study suggest that these large differences in time had a significant effect on their findings. Lastly, although identification of individual organisms is not possible with this technique, relative abundance and density estimates of the community as a whole are not biased by the differ- 
ences in net avoidance between species. The spatial and temporal information provided by acoustic techniques gives new insight into the behavior and dynamics of the mesopelagic boundary community.

Density estimates obtained through echo energy integration do have several limitations. In a multispecies assemblage, particularly a community composed of many different taxa, it is impossible with a single- beam, single-frequency system such as that used here to separate the effects of density and species composition on changing target strengths. It is also impossible to look at the effects of changing aspect of the animals. Because of this, the target strength used to calculate density was conservatively high (see Eq. 2), $14 \mathrm{~dB}$ higher than the target strength at $200 \mathrm{kHz}$ predicted by the general length-target strength relationship given by Urick (1983) for a $5 \mathrm{~cm}$ fish (the mean length of all mesopelagic boundary community fish species reported by Reid [1994]). Fishes are likely to have the highest length-target strength relationship of all the taxa in the boundary community (Arnaya et al. 1989, Imazeki et al. 1989), further overestimating the community's mean target strength. This high estimated target strength should account for overestimates of density that could be caused by problems of net avoidance that might bias Reid's estimate of average fish length, problems with changing target strength with tilt angle, and differences in target strength for different taxa, still yielding estimates of density that are biased towards lower rather than higher values. Other problems with the echo-energy integration technique such as thresholding and shadowing would also cause density to be underestimated. However, patterns in density would still be conserved and the high estimates of density obtained from this work necessitated this conservative method. Because of the difficulties in interpreting density information, the data was also analyzed as relative abundance, which does not suffer from the same assumptions. Both methods revealed similar patterns, with a wide range of values from $0 \%$ to nearly $100 \%$ for relative abundance and 0 to 1800 organisms $\mathrm{m}^{-3}$ for density, giving us confidence in the interpretation of the results.

Acoustic data also cannot identify species or look at species-specific spatial patterns. However, MOCNESS samples show that nearly all micronektonic organisms captured by the trawl in the range identified acoustically as the range of the layer were components of the mesopelagic boundary community. Net avoidance by micronektonic organisms is most certainly a problem for the MOCNESS trawl. However, it is reasonable to assume that the trawl is giving an accurate representation of the proportion of boundary community animals in the micronekton, given that equally sized animals in the boundary community and those that are not com- ponents of the boundary community are relatively equally mobile. Acoustic data from the 25 to $50 \mathrm{~m}$ and 100 to $150 \mathrm{~m}$ depth range taken during MOCNESS trawls and acoustic data taken at other times and locations show similar characteristics, suggesting that the organisms that reflected signals were the same in both cases. The absence of acoustic returns in all other depth strata sampled by the MOCNESS trawls suggests that organisms captured in the trawls at these depths did not have sufficient backscatter cross-sections to be observed by the echosounder. These organisms were not likely to have been confounding the depths identified acoustically as being part of the layer, ruling out many possible sources of scatterering. Although it is impossible to rule out all other organisms that might be present in acoustic returns, if trawl data are representative of the community at the depths of interest, mesopelagic boundary community organisms are the principal micronektonic source of scattering. Preliminary video data support the conclusion that mesopelagic organisms are indeed the sources of the scattering. It is also unlikely that the organisms measured with the echosounder are planktonic, as the minimum target strength measured was $-59 \mathrm{~dB}$. The target strength of the types of the most common plankton in Hawaiian waters at $200 \mathrm{kHz}$ ranges from -73 to $-89 \mathrm{~dB}$, even when densely clumped (Greene \& Wiebe 1990, Ehrenberg \& Torkelson 1996, Huse \& Ona 1996, Gal et al. 1999).

The waters off the Waianae coast of Oahu consistently had a higher relative abundance of organisms as well as higher densities of organisms than the Kona coast of Hawaii. The relative abundance of organisms in shallow water off Waianae was higher than $80 \%$ for over $10 \mathrm{~km}$. Off Kona, it was a less predictable $50 \%$, but the layer was clearly evident for nearly $30 \mathrm{~km}$. Maximum densities off Waianae are conservatively estimated at 1800 organisms $\mathrm{m}^{-3}$ of water in inshore waters. Densities reached only less than half that in Kona, 700 organisms $\mathrm{m}^{-3}$. However, the extent of the vertical distribution of organisms in inshore waters off the Kona coast far exceeded that of inshore Waianae locations. The boundary layer, in avoiding the bottom and the surface (Reid et al. 1991), appears to become packed in midwater. The reasons for the dense packing of animals in the boundary community are unclear. It would seem to have negative consequences on the respiration and foraging efficiency of these closely spaced individuals. However, the impact on predation risk may be beneficial (Suh \& Yu 1996). It is important to notice that these high densities only occur in the areas closest to the shoreline, and then are found only in some patches and do not extend over large areas.

The mesopelagic boundary community approaches the shores of the Hawaiian Islands much more closely 
than previously thought. High densities of midwater organisms were found less than $1 \mathrm{~km}$ from shore. It is clear that these waters, which rarely have depths great enough for the daytime habitat of these vertically migrating organisms (400 to $1200 \mathrm{~m}$ [Young 1983]), are not being populated with mesopelagic organisms simply through vertical migration. In areas close to shore, the continuous increase of the relative abundance and density of organisms until the midpoint between sunset and sunrise, followed by a reciprocal decrease in the same measures until dawn suggests an input and output of organisms. This is further supported by data from offshore sampling locations where there is an increase in organisms until around 21:00 h, followed by a decrease at midnight and another increase at around 03:00 h. This suggests that organisms are moving through this location twice. This could be due either to 2 complete vertical migrations, animals moving both upwards and downwards twice in a single evening, or to a horizontal movement through the area first in one direction, and then in the other. Two vertical migrations have never been observed in these organisms, and this does not fit the data from the inshore transects. It seems likely that the community is moving inshore and upwards until the approximate midpoint of the night and then offshore and downwards again. This pattern is consistent between the leeward coasts of Oahu and Hawaii. The pattern is also consistent between days and between the 2 times of year observed. The boundary community appears to regularly undergo a diel horizontal migration in conjunction with its well-documented vertical migration.

The organisms that are observed using the acoustic techniques are likely to represent only part of the mesopelagic boundary layer, perhaps a component with a different tactic that may merit a more specific definition. Not all of the animals in the boundary community migrate vertically (Reid et al. 1991, Reid 1994), so consequently not all of the animals in the boundary community could reach depths that would allow them to be over the shallow bottoms found near the coast. It is also possible that not all the vertically migrating animals in the boundary community migrate horizontally. The trough in relative abundance and density of organisms around midnight in offshore sampling locations suggests that there is not a continuous input of organisms into these waters. Combining this with the 2 layers of organisms that are evident in the vertical distribution, there may be 2 distinct strategies present. One group of organisms is moving into the nearshore areas, while the other is remaining further out. At midnight, these offshore sampling locations may be catching the trailing edge of one part of the community and the leading edge of another migrating vertically or both horizontally and vertically.
The patterns of the horizontal component of the diel migration in the mesopelagic boundary community are linked with the distance of the observation from the shoreline, rather than the depth of the location. The inshore sites off the Kona coast, regardless of their depth, exhibited a similar pattern to those in the shallow, inshore Waianae sites. The offshore sites exhibited patterns in relative abundance and density that closely matched those observed in the deeper, offshore Waianae sites; again depth was not an important factor. This suggests that organisms are migrating to waters affected by the coast rather than to search for specific bottom types. Data on relative abundance showed that bottom type had a significant effect, which could be caused by the interaction of currents and the topography trapping boundary animals or their prey, or preference of their prey for spatially heterogeneous habitats (Hunter \& Price 1992). However, the direction of the effect of bottom type changed with time and the difference in relative abundance between the 2 bottom types was less than $10 \%$. This difference did not show up in the density of organisms. We hypothesize that the horizontal component of the migration of the mesopelagic boundary community increases the food available to these organisms by bringing them closer to land-based nutrient inputs, productive shallow waters, and possibly upwelling areas. Over the first $100 \mathrm{~m}$ of the water column, the concentration of chlorophyll $a$ at inshore locations off the Kona coast was approximately 10 to $15 \%$ higher than at offshore locations. There was an increase in both the relative abundance and density of organisms in an area that showed particularly high levels of chlorophyll $a$ and low surface salinity. In any case, the reasons for the nighttime horizontal migration of the boundary community are probably similar to the reasons for its upward migration, and its offshore migration is probably driven by the same forces driving the boundary community's downward migration as morning approaches.

Observations on the correlation between nutrient input and primary productivity need to be further studied to test the hypothesis that resource availability is driving the horizontal component of the migration of the mesopelagic boundary community. However, the qualitative assessments of patterns associated with chlorophyll $a$, in combination with the repeated and predictable patterns of horizontal component of the migration observed, suggest a benefit to the horizontal component to the migration of this community rather than an incidental effect of topography or oceanography. First, the pattern is conserved between coasts with different bottom topography. Second, the pattern is relatively symmetrical-organisms seem to be moving inshore and offshore at approximately the same rates. Current 
patterns do not typically change on the scale of time required to allow the community to be involved purely in passive transport. Lastly, there was no significant effect of the direction of current on the patterns of relative abundance and density observed off the Kona coast.

The proximate mechanisms for the horizontal component of the diel migration of the mesopelagic boundary community cannot be determined from this study. As the horizontal migration is a component of the vertical migration of these animals, it is likely that some mechanisms triggering and controlling the horizontal migration are the same as those controlling the vertical migration, and that others interact. Perhaps turbidity, salinity, temperature, prey abundance, or other offshore-onshore gradients are used by the animals to orient towards and away from the shoreline. Although the animals in the layer do not come in contact with the bottom, perhaps a characteristic of the island's slope is involved in cueing the migration. It is not known how these animals remain in the narrow boundary zone over the slopes of the islands (Reid et al. 1991), and it is likely that the mechanisms of maintenance of their position over the slopes are related to the mechanisms of horizontal migration.

The importance of the movement of the mesopelagic boundary community into the nearshore waters of the Hawaiian Islands should not be underestimated. First, this horizontal component of the migration sheds new light on the life histories and physiological and evolutionary constraints of the organisms in this community. Second, the diel horizontal component to the migration of the mesopelagic boundary layer provides a clear mechanism for this community to link the nearshore and oceanic ecosystems in the islands. The dynamic habitat structure that this migration creates is likely to affect the patterns in relative abundance and density of the mesopelagic boundary community's many predators, at many scales, as predators tend to congregate in areas of high prey densities (Sih 1984). The predictability of the migration of the mesopelagic layer around the islands may shed light on the complex patterns of movement observed in its predators: for example, the twice nightly movements of large onaga Etelis coruscans tens of meters off the bottom (C. Kelley pers. comm.), or the inshore-offshore nocturnal movements of Hawaiian spinner dolphin Stenella longirostris (Norris et al. 1994). An understanding of the temporal structure in the mesopelagic boundary community is crucial to understanding its role in the nearshore and oceanic ecosystems in the Hawaiian Islands.

Acknowledgements. We would like to thank Kimberly Andrews, Carmen Bazua, and Scott Murakami for assistance with fieldwork; Christopher Bird for assistance with construc- tion and installation of the transducer mount, computer programming, and fieldwork; and Christopher Kelley for assistance with ArcView processing. Dieter Lammers graciously donated boat time. The National Marine Fisheries Service's Honolulu Laboratory generously provided ship time aboard the 'Townsend Cromwell' and Chief Scientist Robert Humphreys kindly worked with us to maximize accomplishment of both his and our cruise objectives. The officers and crew of the 'Townsend Cromwell' provided excellent scientific support, especially Phil White. We would also like to thank Bruce Mundy for providing data from MOCNESS trawls and Mark Latham of Computrol for providing invaluable assistance in modifying the echosounder. Tom Clarke, D. Van Holliday, Paul Nachtigall, Richard Young, and 3 anonymous reviewers made helpful comments on earlier drafts of this manuscript. The University of Hawaii SeaGrant College provided financial assistance via a project development grant to W.W.L.A. The Leonida Family provided financial support to K.J.B.-B. through their scholarship fund. This is HIMB contribution 1104 .

\section{LITERATURE CITED}

Aecos for the US Army Corps of Engineers (1981) Oahu coastal zone atlas. Aecos, Honolulu, HI

Amesbury SS (1975) The vertical structure of the midwater fish community off leeward Oahu, Hawaii. PhD dissertation, University of Hawaii, Honolulu

Arnaya IN, Sano N, Iida K (1989) Studies on acoustic target strength of squid. II. Effect of behaviour on averaged dorsal aspect target strength. Bull Fac Fish Hokkaido Univ 40:83-99

Benoit-Bierd KJ, Au WWL (2001) Target strength measurements of animals from the Hawaiian mesopelagic boundary community. J Acoust Soc Am (in press)

Comeau S, Boisclair D (1998) Day-to-day variation in fish horizontal migration and its potential consequence on estimates of trophic interactions in lakes. Fish Res (Amst) $35: 75-81$

DeMeester L, Mass S, Dierckens K, Dumon HJ (1993) Habitat selection and patchiness in Scapholeberis: horizontal distribution and migration of $S$. mucronata in a small pond. J Plankton Res 15:1129-1139

Ehrenberg JE, Torkelson TC (1996) Application of dual-beam and split-beam target tracking in fisheries acoustics. ICES J Mar Sci 53:329-334

Enright JT (1977) Diurnal vertical migration: adaptive significance and timing. Limnol Oceanogr 22:856-886

Gal G, Rudstam LG, Greene CH (1999) Acoustic characterization of Mysis relicta. Limnol Oceanogr 44:371-381

Greene CH, Wiebe PH (1990) Bioacoustical oceanography: new tools for zooplankton and micronekton research in the 1990s. Oceanography 3:12-17

Haight WR, Parrish JD, Hayes TA (1993) Feeding ecology of deepwater lutjanid snappers at Penguin Bank, Hawaii. Trans Am Fish Soc 122:328-347

Hassett RP, Boehlert GW (1999) Spatial and temporal distributions of copepods to leeward and windward of Oahu, Hawaiian Archipelago. Mar Biol 134:571-584

Haury LR, McGowan JA, Wiebe PH (1978) Patterns and processes in the time-space scales of plankton distributions. In: Steele JH (ed) Spatial pattern in plankton communities. Plenum Press, New York, p 277-327

He X, Bigelow KA, Boggs CH (1997) Cluster analysis of longline sets and fishing strategies within the Hawaii-based fishery. Fish Res (Amst) 31:147-158 
Holliday DV, Pieper RE (1995) Bioacoustical oceanography at high frequencies. ICES J Mar Sci 52:279-296

Hunter MD, Price PW (1992) Playing chutes and ladders: heterogeneity and the relative roles of bottom-up and topdown forces in natural communities. Ecology 73:724-732

Huse I, Ona E (1996) Tilt angle distribution and swimming speed of overwintering Norwegian spring spawning herring. ICES J Mar Sci 53:863-873

Imazeki A, Yonemoto H, Saotome Y, Isouchi T, Hamada Y (1989) Multifrequency measurements of target strength of the sergestid shrimp Sergia lucens. J Tokyo Univ Fish 76:37-44

Karl DM, Hebel DV, Bjorkman K, Letelier RM (1998) The role of dissolved organic matter release in the productivity of the oligotrophic North Pacific Ocean. Limnol Oceanogr 43: 1270-1286

Kenchington TJ (1989) Estimation of catchability coefficients. Mar Biol 101:24-35

Kennett JP (1982) Marine geology. Prentice-Hall, Engelwood Cliffs, NJ

Koslow JA, Kloser R, Williams A (1997) Pelagic biomass and community structure over the mid-continental slope off southeastern Australia based upon acoustic and midwater trawl sampling. Mar Ecol Prog Ser 146:21-35

Lindstrom M (1991) Factors affecting the horizontal migration of the amphipod Pontoporeia affinis Lindstrom. 1. Recording method and response to water currents. J Exp Mar Biol Ecol 150:149-162

MacLennan DN, Simmonds EJ (1992) Fisheries acoustics. Chapman \& Hall, New York

Medwin H, Clay C (1998) Fundamentals of acoustical oceanography. Academic Press, San Diego

Norris KS, Wursig B, Wells RS, Wursig M (1994) The Hawaiian spinner dolphin. University of California Press, Berkeley, CA

Omori M, Ohta S (1981) The use of underwater camera in studies of vertical distribution and swimming behaviour of a sergestid shrimp, Sergia lucens. J Plankton Res 3: 107-121

Reid SB (1994) Spatial structure of the mesopelagic fish community in the Hawaiian boundary region. PhD dissertation, University of Hawaii, Honolulu

Reid SB, Hirota J, Young RE, Hallacher LE (1991) Meso-

Editorial responsibility: Otto Kinne (Editor),

Oldendorf/Luhe, Germany pelagic-boundary community in Hawaii: micronekton at the interface between neritic and oceanic ecosystems. Mar Biol 109:427-440

Roe HSJ (1974) Observations on the diurnal vertical migrations of an oceanic animal community. Mar Biol 28:99-113

Rogers AD (1994) The biology of seamounts. Adv Mar Biol 30:305-351

Sasaki M (1914) Observations on Hotaru-ika, Watasenia scintillans. J Coll Agric Hokkaido Univ 6:75-107

Shaw RG, Mitchell-Olds T (1993) ANOVA for unbalanced data: an overview. Ecology 74:1638-1645

Sih A (1984) Optimal behaviour and density-dependent predation. Am Nat 12:314-326

Simmonds EJ, Williamson NJ, Gerlotto F, Aglen A (1992) Acoustic survey design and analysis procedure: a comprehensive review of current practices. ICES Coop Res Rep 187:1-127

Skillman RA (1998) Central pacific swordfish, Xiphias gladius, fishery development, biology, and research. NOAA Tech Rep NMFS 142:101-124

Struhsaker P (1973) A contribution to the systematics and ecology of Hawaiian bathyal fishes. PhD dissertation. University of Hawaii, Honolulu

Suh HL, Yu OH (1996) Diel horizontal migration of planktonic copepods in the surf zone of Yongil Bay, Korea. J Korean Fish Soc 29:527-536

Suh HL, Jo SG, Kim KY (1995) Diel horizontal migration of the two mysids Archaeomysis kokuboi and Acanthomysis sp. in the sandy shore surf zone of Yongil Bay, Eastern Korea. J Korean Soc Oceanogr 30:523-528

Underwood AJ (1997) Experiments in ecology. Cambridge University Press, New York

Urick RJ (1983) Principles of underwater sound. McGraw Hill, New York

Webb P, Wooldridge TH (1990) Diel horizontal migration of Mesopodopsis slabberi (Crustacea: Mysidacea) in Algoa Bay, Southern Africa. Mar Ecol Prog Ser 62:73-78

White MG (1998) Horizontal distribution of pelagic zooplankton in relation to predation gradients. Ecography 21: $44-62$

Young RE (1983) Oceanic bioluminescence: an overview of general functions. Bull Mar Sci 33:829-845

Submitted: June 26, 2000; Accepted: November 23, 2000

Proofs received from author(s): July 16, 2001 